Diabetologia 8, 287-291 (1972)

C by Springer-Verlag 1972

\title{
Human Adipocyte Volumes: Maximum Size, and Correlation to Weight Index in Maturity Onset-Diabetes
}

\author{
W. Leonhardt, M. Hanefeld, H. Schneider and H. Haller \\ Department of Internal Medicine, Medical Academy of Dresden
}

Received: October 14, 1971, accepted: January 31, 1972

Summary. Adipocytes of man and rat were isolated by incubation with collagenase. Their size distributions were measured with the pulse counter ZG 2 and evaluated on a lognormal base. Empirically, we have found that the standard deviations of the distributions are negatively correlated with the cell diameter. By extrapolation of the standard deviations to zero, we calculated upper limits of the adipocyte volumes to be $v_{m}=0.93 \mathrm{nl}$ (subcutaneous adipose tissue of the abdomen in man) and $v_{m}=0.49 \mathrm{nl}$ (epididymal and retroperitoneal adipose tissue in white wistar rats). Larger adipocyte volumes in these tissues have not been observed. - The correlations between adipocyte volume $v$ and relative body weight $\mathrm{m} / \mathrm{m}_{0}$ have been measured in non-diabetics (I) and maturity onsetdiabetics (II) separately: $m / m_{0}=2.34 v+0.45$ (I), and $m / m_{0}=0.576 v+0.95$ (II). The regression coefficients in both equations are significantly different: adipocyte volumes increase more directly with weight index in maturity onset-diabetics. Supposing that overweight is an excess of adipocyte mass, we have derived a general relation between weight index $\mathrm{m} / \mathrm{m}_{0}$, adipocy te volume $v$ and $N / m_{0}$, the adipocyte number per $\mathrm{kg}$ body mass: $m / m_{0}=0.93 N v / m_{0}+0.79$. It follows with the above mentioned regression coefficients that obese maturity onset-diabetics have smaller adipocyte numbers than obese non-diabetics. This means that the predisposition to maturity onset-diabetes is extreme in those obese persons who got their overweight after the end of adolescence.

Volume des cellules adipeuses chez l'homme: taille maximum et corrélation avec l'index de poids dans le diabète de l'âge mûr

Résumé. Chez l'homme et le rat, des cellules adipeuses ont été isolées par incubation avec la collagénase. Les répartitions d'après leur taille ont été faites à l'aide du compteur à impulsions $Z G 2$ et évaluées sur une baso lognormale. De façon empirique, nous avons trouvé que les déviations standard dans les répartitions sont en corrélation négative avec le diamètro des cellules. Par extrapolation des déviations standard au zéro, nous avons calculé les limites supérieures du volume des cellules adipeuses de $v_{m}=0.93 \mathrm{nl}$ (tissu adipeux souscutané de l'abdomen chez l'homme) et $v_{m}=0.49 \mathrm{nI}$ (tissu adipeux épididymaire et rétropéritonéal chez le rat blanc Wistar). Des volumes plus grands de cellules adipeuses n'ont pas été observés dans ces tissus. Les corrélations entre le volume $v$ des cellules adipeuses et le poids corporel relatif $\mathrm{m} / \mathrm{m}_{0}$ ont été mesurées séparément chez des non-diabétiques (I) et chez des malades avec diabète établi tardivement (II): $m / m_{0}=2.34 v+0.45(\mathrm{I})$, et $m / m_{0}=0.576 v+$ 0.95 (II). Les coefficients de régression dans les deux équations sont différents de façon significative: les volumos des cellules adipeuses augmentent plus fortement avec l'index de poids chez les malades avec diabète établi tardivement. Si nous supposons que l'excès de poids est un excès de la masse des cellules adipeuses, nous avons une relation générale entre l'index de poids $m / m_{0}$, le volume $v$ des cellules adipeuses et $N / m_{0}$, le nombre de cellules adipeuses par $\mathrm{kg}$ de poids corporel: $m / m_{0}=0.93$ $N v / m_{0}+0.79$. D'après les coefficients de régression mentionnés ci-dessus, il en résulte que les malades obèses au diabète établi tardivement ont un nombre plus réduit de cellules adipeuses que les malades obèses non-diabétiques. Cela signifie que la prédisposition au diabète établi tardivement est extrême chez les personnes obèses qui le sont devenues après la fin de l'adolescence.

Menschliche Fettzellvolumina: Maximale Größe und Korrelation zum Gewichtsindex bei spät-manifesten Diabetikern

Zusammenfassung. Fettzellen des Menschen und der Ratte wurden durch Inkubation mit Kollagenase isoliert. Die Größenverteilungen wurden mit dem Impulszähler $\mathrm{ZG} 2$ gemessen und auf lognormaler Basis ausgewertet. Fimpirisch stellten wir fest, da $\beta$ die Standardabweichun. gen der Verteilungen negativ zum Zelldurchmesser korreliert sind. Durch Extrapolation der Standardabweichun. gen auf Null berechneten wir die oberen Grenzen der Fettzellvolumina von $v_{m}=0.93 \mathrm{nl}$ (subcutanes Fettgewebe des menschlichen Abdomens) und $v_{m}=0.49 \mathrm{nl}$ (epididy. males und retroperitonsales Fettgewebe von weißen Wistar-Ratten). Größere Fettzellvolumina wurden in diesen Geweben nicht beobachtet. Die Korrelationen zwischen dem Fettzellvolumen $v$ und dem relativen Körpergewicht $m / m_{0}$ wurden für Nichtdiabetiker (I) und spät-manifeste Diabetiker (II) getrennt gemessen: $m / m_{0}=2.34 v+0.45$ (I) und $m / m_{0}=0.576 v+0.95$ (II). Die Regressionskoeffizienten beider Gleichungen sind signifikant verschieden: Die Fettzellvolumina nehmen bei spätmanifesten Dia. betikern stärker mit dem Gewichtsindex zu. Unter der Voraussetzung, daß Ửbergewicht ein Überschuß an Fett. zellmasse ist, haben wir eine generelle Beziehung zwischen dem Gewichtsindex $m / m_{0}$, dem Fettzellvolumen $v$ und $N / m_{0}$, der Fettzellzahl pro kg Körpergewicht, abgeleitet: $m / m_{0}=0.93 \mathrm{Nv} / m_{0}+0.79$. Es folgt mit den obigen Regressionskoeffizienten, daß übergewichtige $\mathrm{Pa}$ tienten mit spät-manifestem Diabetes eine kleinere Anzahl von Fettzellen haben als übergewichtige Nichtdiabetiker. Dies bedeutet, daß die Prädisposition zum spätmanifesten Diabetes in den übergewichtigen Personen extrem ist, die erst nach dem Wachstumsalter oin Übergewicht erlangten.

Key words: Human adipocytes, Rat adipocytes, Adipocyto volume, Maximum adipocyte volume, Weight index, Diabetes mellitus, Obesity, Pathogenesis of maturity onset-diabetes. 
Several investigators have agreed that storage of excess calories as triglycerides into fat tissue causes an increase in the adipocyte volumes $[1-14]$. An additional rise of the cell number during overnutrition was described by Bjurulf [15], and in the case of overweight exceeding $70 \%$, by Preiss et al. [16]. In the other extreme, Martinsson [17] only found the adipocyte number, but not the adipocyte size, correlated with the weight index. A distinction between hypertrophy and hyperplasia of the adipose tissue is of great practical importance, since there exists a positive correlation between adipocyte volume and basal lipolysis $[8,13,18]$. Elevated serum concentrations of free fatty acids in obesity cause a metabolic situation which promotes the manifestation of maturity onset-diabetes $[19-21]$. To examine this question further, we have measured the correlation between adipocyte volume and weight index in non-diabeties and maturity onset-diabetics separately.

The concept of exclusive fat cell hypertrophy in obesity includes, at high weight indices, the growth of hypothetically big fat cells. In this connection, we have searched for the existence of a maximum adipocyte volume, analyzing the standard deviations of adipocyte diameter distributions.

\section{Materials and Methods}

Adipose tissue weighting from 2 to $4 \mathrm{~g}$ was drawn by biopsy from the subcutaneous tissue of the abdomen in maturity onset-diabetics and non-diabetics. In part, samples were taken from patients twice: before and after weight reduction by a fasting regime [22]. In animal experiments, epididymal and retroperitoneal fat pads were taken from white male wistar rats of different weights. We isolated the adipocytes in plastic vessels containing Krebs-Ringer bicarbonate buffer and collagenase by the method of Rodbell [23], as earlier described $[9,10] .40 \mathrm{ml}$ of the cell suspensions containing 4000 to 8000 cells per millilitre of saline was measured with the pulse counter ( $Z G$ 2, VEB Transformatoren- und Röntgenwerk Dresden). Passing a jet of $200 \mu \mathrm{m}$ diameter, the suspended cells produce pulses of electrical voltage, which are counted and assorted in their magnitude. The cell diameters were calculated from geometrical and electrical parameters of the counting systeme, without calibration [24]. In contrast to the microscopical method, by the pulse counting in the course of a few minutes are measured several thousand adipocytes in three dimensions. This ensores a high statistical validity of the results. The evaluation is based an a lognormal distribution. In Gaussian distribution paper, the sum percentiles are performed against the logarithm of cell diameters in one population. From the straight line, the standard deviation $s=0.5 \log [d(84 \%) / d(16 \%)]$ and the median cell diameter $d$ are read. The latter cannot be used immediately to calculate the arithmetic mean of the volume on account of the non-symmetry of the volume distribution. The mean diameter $d_{v}$ of this distribution was calculated from the median diameter $d$ and the standard deviation $s$ by the formula ([25], and Leonhardt, unpublished):

$$
\log d_{v}=\log d+4.539 s^{2}
$$

This formula is different from the approximative expression given by Hirsch and Gallian on the base of a normal distribution of the diameters [26]. $d_{v}$ was taken to calculate the mean cell volumes.

\section{Results \\ Distribution type and maximum of adipocyte sizes}

As a preliminary result of 40 probit analyses with the computer $\mathbf{R}-300$ (Volke and Leonhardt, unpublished), the lognormal type holds for the diameter distribution of adipocytes with the same probability as the normal type. Further work will be done by us to confirm the usefulness of the lognormal distribution.

Diameter distributions measured with the pulse counter are relative small, with standard deviations in the range from 0.03 to 0.15 (Fig. 1 and 2). In comparing measurements of adipocyte suspensions by the microscopical method, using a Zeiss eyepiece micrometer, the median diameters agreed with those from the pulse counter method. However, the distributions were broadly dispersed, and tended to be of the normal type, as in general assumed in the literature (e.g. by Hirsch and Gallian [26]). We have calculated (Leonhardt, unpublished) that this is an artefact by superimposion of the statistical error of small numbers ( 200 cells per measurement).

Empirically we have found that the lognormal standard deviations $s$ decrease with the cell diameter. This holds for the adipocyte populations of nondiabetics and diabetics (Fig. 1), and of epididymal and retroperitoneal fat tissue of the rat (Fig. 2). Extrapolation of the regression lines to $s=0$ leads to the diameter of adipocyte populations which contain only one cell size. Obviously, these are maximum adipocyte sizes. We calculated the following maximum diameters $d_{m}$ and maximum volumes $v_{m}$ ( \pm single standard deviation):

$$
\begin{array}{ll}
d_{m}=121 \pm{ }_{9}^{10} \mu \mathrm{m} & v_{m}=0.93 \pm 0.19 \mathrm{nl} \quad(\mathrm{man}) \\
d_{m}=98 \pm 4 \mu \mathrm{m} & v_{m}=0.49 \pm 0.06 \mathrm{nl} \quad \text { (rat). }
\end{array}
$$

The values of the both species are significantly different $(p<0.001)$.

\section{Adipocyte volumes and weight index}

We have examined the correlations between the two parameters in non-diabetics and maturity onsetdiabetios separately (Fig. 3 and 4). The calculated regression equations are:

non-diabetics

$$
m / m_{0}=2.34 v+0.45 \quad r=0.782
$$

maturity onset-diabetics

$$
m / m_{0}=0.576 v+0.95 \quad r=0.570 \quad \text { (eq. } 3 \text { ) }
$$

The regression coefficients are significantly different $(p<0.001) . v$ is the adipocyte volume in $\mathrm{nl} ; \mathrm{m} / \mathrm{m}_{0}$ 
means the relative body weight $=$ actual weight/ average weight, given by the Society of Actuaries 1959 [25].

\section{Discussion}

The adipocyte volumes and correlations to the weight index measured by us agree with recently published data of other authors $[7,8,13,14]$. Further-

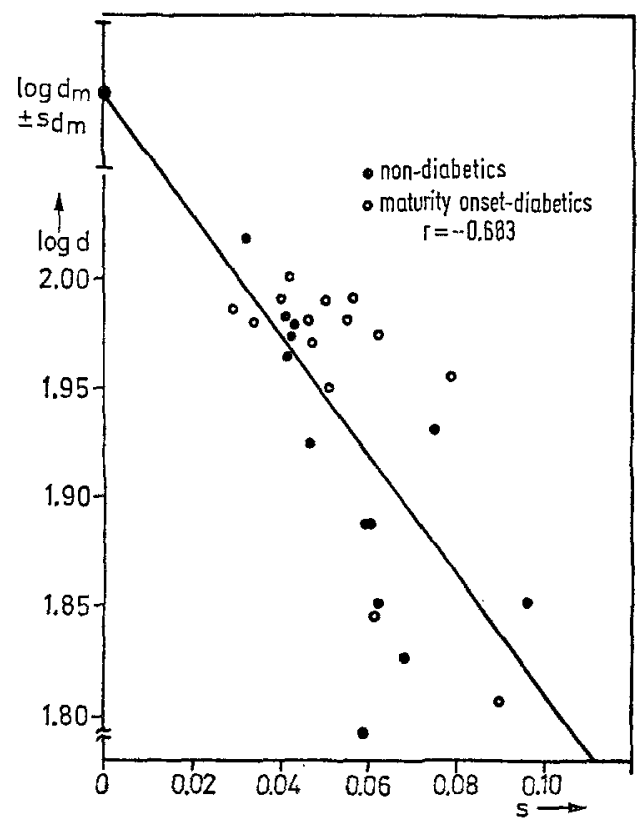

Fig. 1. Correlation between the standard deviation $s$ and $\log d$ of human adipocytes

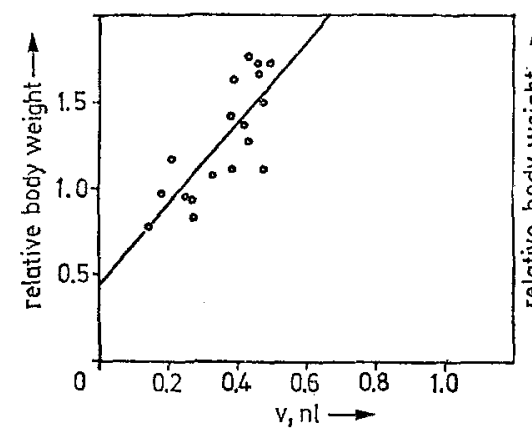

Fig. 3. Correlation between relative body weight and adipocyte volume in non-diabetics

more, by the pulse counting technique it was possible to analyze the standard deviation and type of adipocyte size distributions. Several arguments favor the lognormal distribution type. In this case, the logarithms of diameter, surface and volume are normally distributed. On the other hand, a normal distribution of the diameter itself would exclude normal distributions of surface and volume. There is no reason to prefer the adipocyte diameter from statistical standpoint. Log- normal distributions are widely spreaded in the biological sciences [25].

Lognormal standard deviations were negatively correlated with the logarithms of adipocyte diameters. Qualitatively, a similiar result can be derived from the data of Bjurulf [27], examining the logarithms of the ranges of adipocyte distributions. Thus, it is possible to calculate maximum adipocyte sizes by extrapolation of the standard deviations to zero. This formal pro-

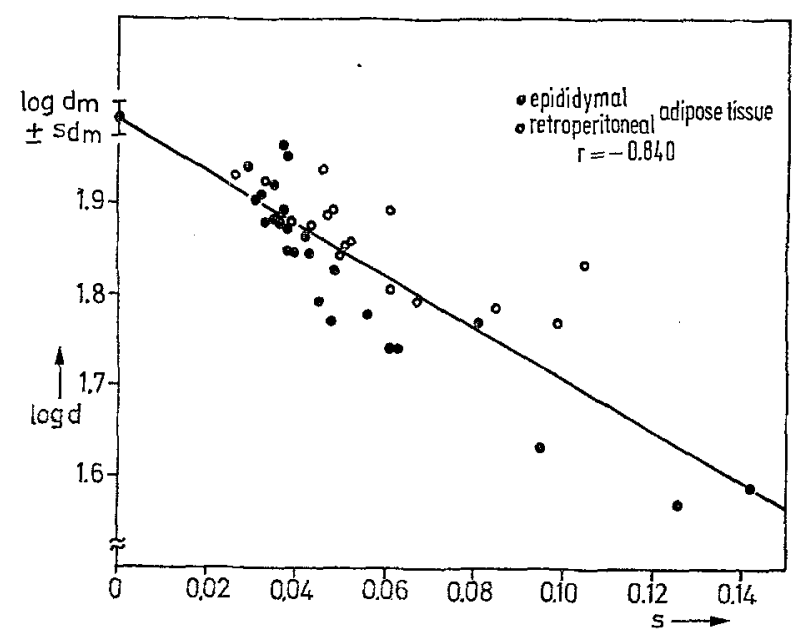

Fig. 2. Correlation between the standard deviation $s$ and $\log d$ of rat adipocytes

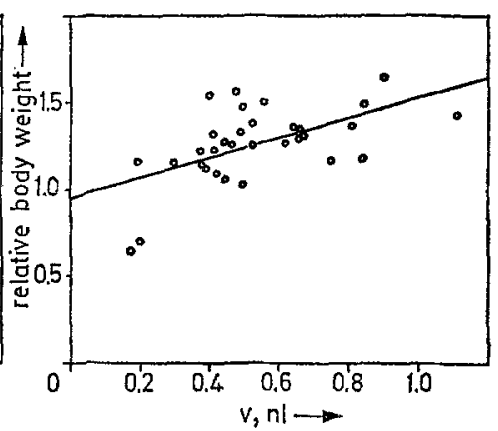

Fig. 4. Correlation between relative body weight and adipocyte volume in maturity onset-diabetics

cedure leads to values which were never exceeded by our measurements, and, as far as can be seen, in the literature $[7,8,13,14]$. There are several reasons for the statement of a maximum adipocyte size, e.g. big cells would be unstable from the mechanical standpoint.

Since the adipocyte size is limited, in very obese persons with weight indices exceeding 1.5 (maturity onset-diabetics) and 2 (non-diabetics) respectively, an 
additional effect of increased adipocyte numbers [14, 15, 16] must be assumed. However, alterations in cell number during starvation and overnutrition was not observed. On the other hand, individual changes in the adipocyte volumes during weight gain [1.2] and weight loss [11] was seen. In our own experiments, these individual changes from the beginning to the end of a weight reduction were parallel to the general regression line between adipocyte volume and weight index [22]. Thus, adipocyte volume changes during dynamic phases of weight in maturity have to be considered as the primary effect. Increased cell numbers could be caused by overnutrition in early childhood or by hereditary factors. They are probably constant in adults and have, as a rule, to be met in persons with very high weight indices. An example is the 19 years female patient E.H. with heredofamilial obesity since childhood. She had the parameters $m / m_{0}=2.60$ and $v=0.47 \mathrm{nl}$ before and $m / m_{0}=2.38$ and $v=0.42 \mathrm{nl}$ after a weight reduction. The position of these data is significantly above the regression line in Fig. 3. From this position we have calculated that, in this case, the amount of overweight is caused by increase of cell volume by $1 / 3$ and cell number by $2 / 3$.

In general, the relation between weight index $\mathrm{m} / \mathrm{m}_{0}$ and adipocyte volume $v$ can be derived by a simple formula, assuming that overweight $m-m_{0}$ is an excess $m_{F}-m_{F 0}$ of white adipocyte mass:

$$
\begin{aligned}
& m-m_{0}=m_{F}-m_{F 0} \\
& \frac{m}{m_{0}}-1=\frac{m_{F}}{m_{0}}-\frac{m_{F 0}}{m_{0}}
\end{aligned}
$$

The actual adipocyte mass $m_{F}$ is determined by the adipocyte number $N$, volume $v$ and density $D$ according to

$$
m_{F}=N D v
$$

$D$ was calculated from data given by Englhardt et al. [14] as $0.93 \mathrm{gcm}^{-3}$.

$m_{F 0} / m_{0}$, the adipocyte content of a normal body, is approximately the normal fat content of $16 \%$ [25], divided by the fat content of adipocytes equal 0.771 [14]:

$$
m_{F 0} / m_{0}=16 \% / 0.771=21 \% \text {. }
$$

Thus, equation 5 can be changed into the form according to the regression lines in Fig. 3 and 4 :

$$
\frac{m}{m_{0}}=\frac{N}{m_{0}} \cdot 0.93 v+0.79
$$

The straight line cuts the $y$ axis at a weight index of 0.79. At this point or in persons with smaller weight indices, subcutaneous fat of the abdominal region will disappear. Lisch et al. [13] found an ordinate section of 0.5 , and from our measurements, we determined ordinate sections of 0.45 and 0.95 in nondiabetics and diabetics, respectively, to be compared with 0.79 . $\mathrm{N} / \mathrm{m}_{0}$, the adipocyte number per $\mathrm{kg}$ normal body mass, can be calculated from the regression coefficients in eq. 2 and 3 . It is in the order of $10^{9}$ adipocytes per $\mathrm{kg}$. At the recent stage of our knowledge, a subtle computation of this value should be avoided, since the adipocyte sizes in different areas of the body vary somewhat [13]. Equation 8 can be modified in a nonlinear form which contributes to the maximum adipocyte volume $v_{m}$ by multiplication of the term $0.93 \mathrm{Nv}$ $m_{0}$ by $v_{m} /\left(v_{m}-v\right)$.

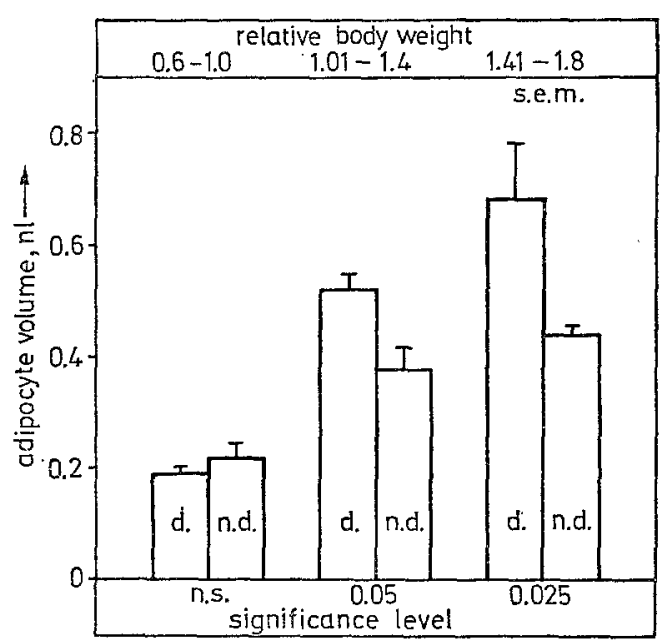

Fig. 5. Mean adipocyte volume in maturity onset-diabetics (d.) and non-diabetics (n.d.) of different body weight

Inspecting eq. 2, 3 and 8 , it is evident that obese maturity onset-diabetics have smaller adipocyte numbers than obese non-diabetics. This means that the predisposition to maturity onset-diabetes is extreme in those obese persons who developed their overweight following adolescence. Their excess triglycerides by overnutrition in maturity have to be stored in relative few adipocytes which increase in volume. This volume effect, increasing with weight index, could be verified statistically. In diabetics and non-diabetics with normal and subnormal body weight, we found no significant difference in the adipocyte volumes. In contrast, in the group with relative body weights ranging from 1.01 to 1.4 , the maturity onset-diabetics had significant larger adipocytes than non-diabetics. This dendency increased in persons with relative body weight from 1.41 to 1.8 (Fig. 5). Thus, our results confirm the importance of the adipocyte volume in the pathogenesis of maturity onset-diabetes.

\section{References}

1. Reh, H.: Die Fettzellgröße beim Menschen und ihre Abhängigkeit vom Ernährungszustand. Virchows Arch. path. Anat. 324, 234-242 (1953).

2. Beste, W.: Die Größe der Fettzellen und ihre Abhängigkeit vom Ernährungszustand. Virchows Arch. path. Anat. 334, 243 (1961). 
3. Hausberger, F.X.: Effect of dietary and endocrine factors on adipose tissue growth. In: Handbook of Physiology, Sect. V. Adipose Tissue. Ed. Renold and Cahill, Jr., p. 519-528. Baltimore: Williams \& Wilkins 1965 .

4. Björntorp, P., Hood, B., Martinsson, A., Persson, B.: The composition of human subcutaneous adipose tissue in obesity. Acta med. scand. 180, 117 (1966).

5. Goldrick, R.B.: Morphological changes in the adipocyte during fat deposition and mobilization. Amer. J. Phys. 212, 777-782 (1967).

6. Hirsch, J., Han, P.: Cellularity of rat adipose tissue Effects of growth, starvation, and obesity. J. Lipid res. $10,77-82(1969)$.

7. Faulhaber, J.D., Ditschuneit, H.H., Ditschuneit, H., Pfeiffer, E.F.: Antilipolytische Wirkung von Insulin an isolierten menschlichen Fettzellen in Abhängigkeit von der Fettzellgröße. Vortrag, Deutscher Diabetes Kongreß, Ulm 1969.

8. Faulhaber, J.D., Petruzzi, E.N., Eble, H., Ditschureit, H.: In-vitro-Untersuchungen über den Fettstoffwechsel isolierter menschlicher Fettzellen in Abhängigkeit von der Zellgröße: Die durch Adrenalin induzierte Lipolyse. Horm. Metab. Res. 1, 80-86 (1969).

9. Hanefeld, M., Leonhardt, W., Haller, H.: Elektronische Messungen der Volumina isolierter Fettzellen beim Versuchstier und beim Menschen. Medicamen. tum 11, 308-311 (1970).

10. Hammermüller, B., Leonhardt, W., Hanefeld, M.: Vorläufige Mitteilung über die elektronische Messung der Volumenverteilungskurven isolierter menschlicher Fettzellen bei Adipositas und ihre Beziehungen zum Diabetes mellitus. Dtsch. Gesundh.-Wesen 43, 2020 2022 (1970).

11. Bray, G.A.: Measurement of subcutaneons fat cells from obese patients. Ann. Int. Med. 73, 565-569 (1970).

12. Salans, L., Horton, E., Sims, E.: Influence of fat cell size and dietary carbohydrate intake on adipose tissue insulin sensitivity in adult onset obesity. Clin. Res. 18, 463 (1970).

13. Lisch, H.-J., Sailer, S., Sandhofer, F., Braunsteiner, H.: I. Beziehungen zwischen relativem Körpergewicht und Zellvolumen. Klin. Wschr. 48, 1349 - 1353 (1971).

14. Englhardt, A., Gries, F.A., Liebermeister, H., Jahnke, K.: Size, lipid and enzyme content of isolated human adipocytes in relation to nutritional state. Diabetologia 7, $51-58$ (1971).

15. Bjurulf, P.: Atherosclerosis and body build with special reference to size and number of subcutaneous fat cells. Acta med. scand. Suppl. 349, 7 (1959).
16. Preiss, H., Hesse-Wortmann, C., Gries, F.A., Jahnke, K. : Die Größe menschlicher isolierter Fettzellen in Abhängigkeit vom Ernährungszustand. Dtsch. Ges. Fettwissenschaft, Tagung Mainz 1967.

17. Martinsson, A.: Hypertrophy and hyperplasia of human adipose tissue in obesity. Pol. Arch. Med. wewnęt. 42, $481-486$ (1969).

18. Smith, U.: Effects of glucose and insulin on lipolysis rates in human fat cells of different sizes. FEBS Letters 11, 8-10 (1970).

19. Randle, P.J., Garland, P.B., Newsholme, E.A., Hales, N.C.: The glucose fatty acid cycle. Its role in insulin sensitivity and the metabolic disturbances of diabetes mellitus. Lancet $1963 \mathrm{I}, 785-789$.

20. Förster, H., Mehnert, H.: Diabetes und Fettsucht. Int. J. clin. Pharmacol., Beiheft Fettstoffwechsel $50-56(1969)$.

21. Haller, H., Leonhardt, W., Hanefeld, M. : Die Wechselwirkung zwischen Fettzellgröße und peripherer Insulinwirkung als manifestationsbegünstigender Faktor des maturity onset-Diabetes. Wiss. Konferenz anläßI. des 50. Jahrestages der Entdeckung des Insulins, Karlsburg, 7. 4. 1971.

22. Leonhardt, W., Zsohornack, M., Julius, U., Schneider, H., Hanefeld, M.: Elektronisch gemessene Fettzelldurchmesser sowie Parameter des Kohlenhydrat- und Fettstoffwechsels vor und nach einer Entfettungskur bei diätetisch eingestellten adipösen Diabetikern. 2. Internat. Donausymposium über Diabetes mellitus, Budapest, 24. - 26. 6. 1971. Kongreßband Wiener Med. Akademie 1971, 135-137.

23. Rodbell, M.: Metabolism of isolated fat cells. J. biol. Chem. 239, 375 (1964).

24. Heidenreich, E.: Ein Beitrag zur Analyse von Mikrokörnungen. Dresden, TU, Dissertation v. 1967.

25. Wissenschaftliche Tabellen. Documenta Geigy. Basel 1968.

26. Hirsch, J., Gallian, E. : Methods for the determination of adipose cell size in man and animals. J. Lipid. Res. 9, 110-119 (1968).

27. Bjurulf, P.: Atherosclerosis and the structure of adipose tissue, a special approach to the interpretation of the association between obesity and atherosclerosis. Pol. Arch. Med. wewnęt. 92, 337-343 (1969).

Prof. Dr. sc. med. H. Haller, Medizin. Klinik

Med. Akademie ,Carl Gustav Carus", DDR-8019 Dresden,

Fetscherstr. 74

German Democratic Republic 